(REvIEW ARTICLE)

\title{
The role of enforcement in environmental protection in Nigeria
}

\author{
Oruonye ED $1,{ }^{*}$ and Ahmed YM 2 \\ 1 Department of Geography, Taraba State University, Jalingo, Taraba State, Nigeria. \\ 2 Department of Geography, Taraba State University, Jalingo, Taraba State, Nigeria.
}

Publication history: Received on 30 June 2020; revised on 06 July 2020; accepted on 08 July 2020

Article DOI: https://doi.org/10.30574/wjarr.2020.7.1.0237

\begin{abstract}
The environment provides life support system to man. So many regulations and laws have been put in place to ensure adequate protection of the environment from man's activities. Government has over the years established institutions that are given the responsibility of enforcing these laws and regulations to ensure compliance. Despite this legislative and institutional frameworks, effective compliance has become a mirage in the country. This paper examines the role of enforcement in environmental protection in Nigeria. The study adopted secondary desk review of existing literature. The findings of the study reveals that environmental regulations are the general rules and specific actions enforced by administrative agencies so as to control pollution and manage natural resources with the purpose of protecting the environment. The study findings reveal that the same government that put these structures in place is the main violator of the policies and provisions to protect the environment. This often leads to an atmosphere of system failure where, nothing works and the environment suffers for it. The benefits of enforcement of environmental regulations include creation of employment opportunities, protection of the environment and environmental sustainability. Some of the challenges of effective compliance to environmental regulations include outdated laws, high cost of environmental standards, weak institutional capacity, poor governance, under staffing, inadequate funding, vested interest, multiplicity of legislation/conflicting laws, ignorance and lack of rule of law among others. The study recommends employment of more staff, increase funding of environmental enforcement agencies, and review of old and outdated environmental laws and regulations.
\end{abstract}

Keywords: Compliance; Enforcement; Environment; Framework; Institution; Regulation

\section{Introduction}

The environment is the natural surroundings of living organisms which include man, animals and plants that live and interact with one another. The environment can also be seen as the combination of external physical conditions such as air, water, soil and plants that affects and influence the growth, development and survival of living organism. The environment provides man with a number of vital services, natural resources, amenities, life support systems and opportunity to dump waste. The environment provides life support system to man.

The environment over the years has undergone numerous changes and modifications by both economic, political and environmental forces, to the extent that the pattern of its evolutionary trend cannot be used with high degree of precision in predicting the nearest future. Human population is increasing very rapidly, especially in the developing countries, leading to expanding urban development, construction works and agricultural practices that are encroaching marginal lands. Similarly, industrialization through pollution is concomitantly threatening life supporting resources on earth. These challenges are further exacerbated by growing natural disasters such as earthquake, volcanic eruption, drought, cyclones, floods and mass wasting among others.

So many regulations have been put in place to enhance the protection of the environment. Nigeria, with a nominal GDP per capita of US $\$ 2,640$, faces numerous challenges from the environment with serious implications for human security,

\footnotetext{
* Corresponding author: Oruonye ED
}

Copyright (C) 2020 Author(s) retain the copyright of this article. This article is published under the terms of the Creative Commons Attribution Liscense 4.0. 
yet policies and institutional frameworks on environment remain comatose [1]. Environmental degradation in different parts of the country appears to coincide with an upsurge of violent conflicts in places especially over the last two decades. Examples include the Niger Delta, Northwest and Northeast regions. In Nigeria, the responsibility to monitor and regulate these emerging challenges and put in place policy and institutions to resolve these problems, or prevent further conflicts/crisis, is mainly on the Federal Ministry of Environment [1].

Beside this, there are so many regulations that have been put in place to ensure adequate protection of the environment from man's activities. There are also many international protocols and conventions that have been signed and domesticated in the country. These protocols, conventions and regulations are backed up by laws in the constitution of the Federal Republic of Nigeria. Government has also gone ahead to establish institutions that are given the responsibility of enforcing these regulations to ensure compliance. The institutions have also come up with many frameworks to ensure effective protection of the environment. Despite this legislative and institutional frameworks, effective compliance has become a mirage in the country which is attributed to poor or lack of enforcement of the regulations. The need to appraise these policies and frameworks became imperative against the background of increasing environment-based threats to human security in spite of the existence of these frameworks in the country. Therefore, the apparent ineptitude of government and its institutions at all levels in Nigeria, in responding to environmental challenges, which have significant connection with insecurity and grave consequences for peace and development across the country, due to their links with a myriad violent conflicts, further reinforces the urgent need to evaluate the policy and institutional frameworks for safeguarding the environment in the country as well as enhancing its positive impact on human development [1]. It is against this background that this paper examines the role of enforcement in environmental protection in Nigeria.

\section{Conceptual Clarification}

\subsection{Compliance}

Compliance is the state of conformity with obligations, imposed by a State, its competent authorities and agencies on the regulated community, whether directly or through conditions and requirements in permits, licences and authorizations [2]. Compliance is defined by the European Union network, 'Implementation and Enforcement of Environmental Law' (IMPEL) as: "full implementation of environmental requirements. Compliance occurs when requirements are met and desired changes are achieved" [3]. Compliance with legal requirements regarding environmental protection should result in appropriate environmental control measures and better environmental performance [4]. The purpose of compliance assessment according to IEMA [4] is to:

- Oversea compliance of regulated businesses and organisations with relevant environmental legal requirements that may involve directly applied regulations, requirements in permits or any other legal obligations that are applicable; and

- Assess from time to time the impact of regulated organisations on the environment in order to ascertain the necessity of further inspection or enforcement action (including granting, issuing, modification or revocation of any permit) as may be needed to secure compliance with environmental legal requirements.

\subsection{Enforcement}

Enforcement is the set of actions that a government or its institution takes to achieve full implementation of environmental requirements (compliance) within the regulated community and to correct or bring to a stop situations or activities that poses threat to the environment or public health [5]. Enforcement can also be seen as the range of procedures and actions employed by a State, its competent authorities and agencies to ensure that organizations or persons, potentially failing to comply with environmental laws or regulations, can be brought or returned into compliance and/or punished through civil, administrative or criminal action [2].

Enforcement can also be seen as actions taken by the government against violators of environmental regulations to compel compliance to the regulation(s) and laws as the case may be. These provisions generally give a governmental entity authority to impose sanctions, in either the administrative, judicial, or criminal forum, and require the violator to come into compliance with the regulation and law. Some statutes contain provisions that require a violator to remedy environmental damage caused by the violations or that allow the government to clean up the damage and recover the cost from the violator [6]. Most enforcement agencies are given powers to assess administrative penalties, issue orders and initiate civil judicial actions against violators [1]. 
Enforcement by the government usually includes inspections to determine the compliance level of the regulated business and community and to ascertain possible violations; negotiations with individuals or facility managers who are out of compliance to develop mutually agreeable schedules and approaches for achievement of compliance [5]. It also involve deployment of legal action when and where necessary to compel compliance and to impose some consequences for violation of the law or endangering public health and the environment; and compliance promotion, such as educational programs, technical assistance, and subsidies, to encourage voluntary compliance [5].

Experience with environmental programs has shown that enforcement is essential to compliance because many people and institutions will not naturally comply with a regulation or law unless there are clear consequences for noncompliance [5]. Enforcement action is taken by regulators to ensure that such businesses or organisations comply with legal requirements of environmental permits and directly applied laws by using: warning letters, enforcement notices, formal cautions and prosecution [4]. Such action is also taken to mitigate the polluting effects of incidents and to prevent further incidents and pollution which may cause serious environmental damage or harm to human health [4]. These include:

- Prohibition notices to stop or prevent illegal and polluting activities;

- Works (anti-pollution) notices to enforce actions needed to mitigate or prevent serious environmental damage or harm to human health; and

- Suspension or revocation of a permission.

In most cases, it is expected that enforcement action will be proportionate to the potential or actual damage to the environment, the level of non-compliance and offences committed.

Types of enforcement

Some of the different types of enforcement are briefly presented below;

Administrative enforcement

Involves a set of actions that regulatory bodies carry out to ensure compliance with environmental requirements. Certain types of sanctions may be included within administrative powers; as might be actions that are non-judicial in nature. Administrative actions derive their power directly from the law, or indirectly (by delegation) from the state (which has executive powers) [2].

Civil enforcement

Implies a set of actions that can help governmental and non-governmental stakeholders and individuals to use civil or alternative remedies to facilitate compliance with, and enforcement of, environmental requirements. Civil society groups and non-governmental actors with environmental expertise that can supplement legal action by the state have their ways of bringing violators into compliance [2].

\section{Criminal enforcement}

This has to do with the imposition of criminal sanctions on violators. Due to a range of factors (including lack of coordination between relevant institutions; lack of an appreciation of environmental crime as being as serious as more 'traditional' crimes; and lack of expertise and financial or technical resources), however, these sanctions are not always as effective as they ought to be [2].

Environmental enforcement is based on environmental laws. An environmental law provides the vision, scope, and authority for environmental protection and restoration. Some environmental laws contain requirements while others specify a structure and criteria for establishing requirements, which are then developed separately. Requirements may be general, in which they apply to a group of facilities, or facility-specific. Examples of environmental enforcement programs include those that govern the ambient environment, performance, technology, work practices, dissemination of information and product or use bans [2].

\subsection{Environmental regulations}

Regulations has been defined by Spulber [7] as "the general rules or specific actions imposed by administrative agencies that interfere directly with the market allocation mechanism or indirectly by altering consumer and firm demand and supply decisions". According to Stavropoulos et al [8], environmental regulations are the general rules and specific actions enforced by administrative agencies so as to control pollution and manage natural resources with the purpose 
of protecting the environment and internalizing externalities, including direct and indirect interventions. Environmental regulation is regarded as a state activity representing effective public administration (Encyclopedia.com). Environmental regulations provide a brake on the indiscriminate discharge of noxious substances into the atmosphere and water courses, and help to discourage the destruction of the Earth's natural systems and cycles, habitats and species [4].

Environmental regulation is a complex interdisciplinary effort involving ethical principles, political interests, scientific knowledge, and technological capacities. Environmental regulation is necessitated by the philosophy of wise use, which is of the believe that resources should be managed for the greatest good, for the greatest number, for the longest time and betterment of society as a whole [8]. Environmental regulation has to do with protection of public goods. Environmental regulation of businesses and other organisations is intended to protect human health and the environment from harm within the context of sustainable development. It has covered the environmental media (air, water and land), together with wildlife protection and conservation. It has focused on the control of polluting emissions and on maintaining and improving water quality and waste management [4].

Environmental regulations involve series of standards designed by regulators to be followed by polluters, or to direct a certain industry to adopt particular technologies in accordance to defined rules and regulations. Administrative agencies can impose sanctions on violators and reward compliers [8]. Environmental regulation is aimed at achieving high environmental standard. However, maintaining high environmental standard often comes with high cost for industries especially those that have great adverse impact on the environment. This is the reason why some countries especially developing countries like Nigeria try to lower standards by adopting less stringent environmental standards to attract more investors and industrial establishment. This in turn result in relaxed regulations which ultimately leads to deterioration of the environment.

Environmental regulations provide for issuing permits, licence and certificates upon application and satisfaction of laid down conditions prior to the issue. These permits, licence and certificates are oftentimes used as the basis of enforcement of environmental regulations. The government use it as a monitoring devise to regulate the activities which are potential sources of threat to the environment. Therefore, the issuance carries with it an understanding that the holder of the permit, licence or certificate will forfeit such upon the breach of the regulations, statute or any of the laid down conditions specified on such permit, licence or certificate [9].

\subsection{Institutions}

Institution is one of the concept that has been used in different context with different meaning especially from legal, political, sociological and economic point of view (Dasgupta and Karl-Goran [10]. According to the World Development Report [11], institutions are rules, enforcement mechanisms and organizations put in place in a country or society. Institution can be seen as consistent and organized pattern of behaviour or activities (established by law or custom) that is self-regulating in accordance with generally accepted norms (http://www.businessdictionary.com/definition/institution.html). For instance, political institutions are involved with (and regulate) competition for power; and economic institutions (such as markets) encourage and regulate production and distribution of goods and services.

Distinct from policies that are the goals and the desired results, institutions are rules, including behavioural norms, by which agents interact, and the organizations that implement these rules and codes of conduct to achieve desired outcomes (http://www.businessdictionary.com/definition/institution.html). According to the Business Dictionary, institution is the establishment, foundation, or organization created to pursue a particular type of endeavour, such as banking by a financial institution.

\section{Results}

\subsection{Environmental Regulation Enforcement in Nigeria}

In an effort to protect the environment from man's excesses, government put in place institutional and legislative framework which include establishing agencies and parastatals and employing people to help enforce it. Government also enacted laws, policies and regulations with penalties and sanctions aimed at protecting the environment. Unfortunately, the same government that put these structures in place is the main violator of the policies and provisions to protect the environment. This development has given rise to the common saying "lack of political will". This leads to system failure in the country as government institutions exist for mere existence without the capacity to carry out their constitutionally assigned responsibilities. In such atmosphere of system failure, nothing works and the environment 
suffers for it. This is even worst at the State and Local Government levels. There is hardly anything like environmental impact assessment in both state government and local council's development projects. There is also nothing like environmental regulations compliance or enforcement. Anything goes as it were. Unemployment continue to increase because even the existing government institutions lack the capacity to make their impact felt or appreciated by the citizens. In Nigeria, we are gradually moving towards system collapse society where nothing works. People have often said that our laws are not working as they ought to and government administrative machinery are also weak and ineffective. There are in existence many policies and regulations as well as international conventions entered into by the Nigerian government. But often times these policies and regulations end up on papers only as they are not implemented nor enforced.

The Nigerian 1999 constitution recognizes the importance of the environment to the overall socioeconomic development of the country and thus, it made provisions for the protection of the Nigerian environment. Section 20 of the 1999 Constitution of the Federal Republic of Nigeria made it clear that the Nigerian State shall protect and improve the natural environment and safeguard the water, air, land, forest and wildlife of Nigeria [1]. In furtherance to the above, the Nigerian government came up with the National policy on the environment. The goals of National Policy on the Environment according to Ichite [1] is to achieve sustainable development in Nigeria, and, in particular, to;

- Secure a quality of environment adequate for good health and wellbeing;

- Conserve and use the environment and natural resources for the benefit of present and future generations;

- Restore, maintain and enhance the ecosystems and ecological processes essential for the functioning of the biosphere to preserve biological diversity and the principle of optimum sustainable yield in the use of living natural resources and ecosystems;

- Raise public awareness and promote understanding of the essential linkages between the environment, resources and development, and encourage individual and community participation in environmental improvement efforts; and

- Co-operate in good faith with other countries, international organisations and agencies to achieve optimal use of transboundary natural resources and for an effective prevention or abatement of transboundary environmental degradation.

\subsection{Examples of Environmental Laws and Regulation in Nigeria}

There are many regulations put in place to protect the environment, however, few are considered below;

Minerals and Mining Acts 2007: Under section 1 of the Act, it state that "the entire property in and control of all mineral resources in, under or upon any land in Nigeria, its contiguous, continental shelf and all rivers, streams and water course throughout Nigeria, any area covered by its territorial waters or constituency and the Exclusive Economic Zone is and shall be vested in the Federal Government of Nigeria for and on behalf of the people of Nigeria". The mining Act also contains provisions for the protection of the environment in the course of mining activity by prohibiting pollution of water courses by mining or mineral prospecting operations.

National Water Sanitation Policy (2004): Defines water sanitation as hygiene practice, handling and disposal of excreta, liquid (sewerage, sullage and storm water) and leachates from dump sites (solid wastes) in so far as it affects water sources.

Water Resources Act: The act vests the rights and control of water in the Federal Government. Under section I (1). The right to the use and control of all surface and groundwater and any water course affecting more than one State as described in the Schedule to this Act, together with the bed and banks thereof, are by virtue of this Act and without further assistance vested in the Government of the Federation.

The Public Health Act 1917: Prohibits the fouling of water and the vitiation of the atmosphere. The Act contains provisions against introduction of any deleterious substance into the various sources of water supply for human and animal consumption.

The EIA Act No. 86 of 1992: Makes EIA mandatory for development projects likely to have adverse impact on the environment. EIA Act was put in place to protect the environment from project construction work in the environment. The EIA process is one of the key ways through which prevention and precaution may be implemented as it aims at an evaluation of the positive or negative environmental consequences of an activity or a strategy [1]. 
Federal Environmental Protection Agency of Nigeria (FEPA): FEPA was created by Decree 58 of December 30, 1988, with the statutory responsibility for the protection and development of the environment in general. It was replaced by the National Environmental Standards and Regulation Enforcement Agency (NESREA). The agency was established by the NESREA establishment Act 2007 LFN and NESREA Act 2018 as amended. NESREA is now the major federal body charged with the protection of Nigeria's environment. It was established on July 30, 2007 as a corporate body with perpetual succession and a common seal, which may sue and be sued in its corporate name. It is responsible for the enforcement of environmental standards, regulations, rules, laws, policies and guidelines. Its authority extends to the enforcement of environmental guidelines and policies, such as the National Policy on the Environment; 1999 [1].

Endangered Species Decree No. 11 was enacted on 24 April 1985. It specifies the penalties for trading in the most precious species (Keystone species). This law was enacted after Nigeria became a signatory to CITES in 1981 . Now it is known as the Endangered Species (Control of International Trade and Traffic) Act Cap. E.9, Laws of the Federation of Nigeria, 2004.

National Environmental (Protection of Endangered Species in International Trade) Regulations, 2011, S.I. No. 15 Gazette No. 42. Vol. 98 of 6th May, 2011. The purpose of the regulation is to protect endangered species of fauna and flora; and prevent their extinction by controlling international trade in their living specimens, parts and derivatives.

Inland-fisheries Act43 and revised Sea Fisheries Act.44

National Environmental (Standards for Telecommunications and Broadcasting Facilities) Regulations, 2011, S.I. No. 11 Gazette No. 38, Vol. 98 of $29^{\text {th }}$ April, 2011. The purpose of the regulation is to protect the environment and human health; ensure safety and general welfare; eliminate or minimise public and private losses due to activities of the telecommunications and broadcast industry.

National Environmental (Soil Erosion and Flood Control) Regulations, 2011, S.I. No. 12, Gazette No. 39 , Vol. 98 of $2^{\text {nd }}$ May 2011. The purpose of the regulation is to protect human life and the environment; minimise losses due to flood and erosion and their effects on vulnerable areas by controlling earth-disturbing activities.

National Environmental (Control of Bush/Forest Fire and Open Burning) Regulations, 2011, S.I. No. 15 Gazette No. 42. Vol. 98 of $6^{\text {th }}$ May, 2011. The purpose of the regulation is to prevent and minimise the destruction of ecosystem through fire outbreak and burning of any materials that may affect the health of the ecosystem through the emission of hazardous air pollutants.

National Environmental (Domestic and Industrial Plastic, Rubber and Foam Sector) Regulations, 2011, S.I. No. 17, Gazette No 44, Vol. 98 of 10th May, 2011. Purpose: to prevent and minimise pollution from all operations and ancillary activities of the domestic and industrial plastic, rubber and foam sector to the Nigerian environment including the control of volatile organic compounds.

National Environmental (Coastal and Marine Areas Protection) Regulations, 2011, S.I. No. 18 Gazette No 45, Vol. 98 of 13th May 2011. The purpose of the regulation is to provide the regulatory framework for preserving the natural ecological conditions of the estuarine system, barrier islands system and the beaches so as to safeguard and perpetuate their natural productivity and their biological, economic and aesthetic values.

National Environmental (Construction Sector) Regulations, 2011, S.I. No. 19, Gazette No. 46. Vol. 98 of 17 th May, 2011. Purpose: to prevent and minimise pollution from construction, decommissioning and demolition activities to the Nigerian Environment.

National Environmental (Control of Vehicular Emissions from Petrol and Diesel Engines) Regulations, 2011, S.I No. 20, Gazette No 47. Vol. 98 of 17th May, 2011. Purpose: to control vehicular emission; and restore, preserve and improve air quality by among others, ensuring regular emission testing and maintenance of automobiles operating the road ways.

National Environmental (Non-Metallic Minerals Manufacturing Industries Sector) Regulations, 2011, S.I. No 21 Gazette No. 48, Vol. 98 of 23rd May, 2011. Purpose: to prevent and minimise pollution from all operations and ancillary activities of the non-metallic minerals manufacturing sector to the Nigerian environment.

National Environmental (Surface and Groundwater Quality Control) Regulations, 2011, S.I. No. 22, Gazette No. 49, Vol. 98 of 24th May, 2011. Purpose: to restore, enhance and preserve the physical, chemical and biological integrity of the nation's surface and ground waters; and to maintain existing water uses. 
National Environmental (Electrical/Electronic Sector) Regulations, 2011, S.I. No 23 Gazette No. 50, Vol. 98 of 25th May, 2011. Purpose: to prevent and minimise pollution from all operations and ancillary activities of the electrical/electronic sector. This Regulation covers both new and used electrical/electronic equipment (EEE/UEEE).

\subsection{Exploring the Benefit of Enforcement of Environmental Regulation}

Creation of employment opportunity

Effective enforcement of environmental laws and regulations has the potential of creating employment opportunities for environmental experts who may want to practice their profession as private consultants. Just like the lawyers that have some members of the profession working in the public sector such as Ministry of Justice, various courts and legal units of corporate organizations, we have others who work as private practitioners. In the same way, we have environmental experts and specialist who work in various government ministries and agencies such as Ministry of Environment, Ministry of Urban development and planning, Ministry of Minerals and Mines and National Environmental Standard Regulation Agency (NESREA), National Oil Spillage and Disaster Regulation Agency (NOSDRA), various States Environmental Protection Agencies (EPAs) etc. The environmental experts and specialist working as private practitioners serve as consultants to various business firms and organizations in carrying out EIAs and Environmental Audits which is a mandatory requirement for issuance of various licences such as EIA certificates for project construction, mining lease and licence, petroleum retail station location permits and GSM mast location permits among others. These official documents which are statutorily required before issuance of mining licence, approval of construction works among others are then vetted by environmental specialist in the public sector. Thus, effective monitoring and enforcement of compliance to the regulations will compel prospective industrialist and investors to carry out such work which in turn creates enormous employment opportunity to a wide range of environmental experts and specialist such as Geographers, Geologist, Hydrologist, Chemist, Botanist, Soil Scientist and laboratory technologist among others.

\section{Protection of the environment}

The enforcement of environmental regulations helps to protect the environment from man's excesses that leads to environmental degradation. This helps to bring about high standard and strict compliance to environmental laws and regulations meant to protect the environment and its resources.

Ensures environmental sustainability

The effective enforcement of environmental regulations helps to achieve environmental sustainability that will enhance the welfare of the citizenry.

- Effective enforcement helps in developing a culture of compliance because it raises awareness that noncompliance will not be tolerated by the State or the community and that environmental non-compliance is poor business behaviour.

\subsection{Challenges to Effective Enforcement of Environmental Regulations}

There is a great wall of difference between policy rhetoric and the behavioural practice on the ground as a result of many challenges which are presented below;

- Out dated laws - some environmental laws such as forestry laws are outdated which stipulates fines of few Naira to offenders. This makes the enforcement of such laws ridiculous [12].

- Environmental regulations and enforcement comes with high cost for businesses and industries. Many businesses and industries cannot operate in an environment with high environmental standard regulations. This makes many developing countries like Nigeria to lower its environmental standard and tolerate environmental pollution and destruction of its environment as seen in the continuous flaring of gas in Niger Delta area of Nigeria.

- Lack of enforcement or effective enforcement of environmental regulations has led to the proliferation of illegal activities in the environment ranging from illegal mining, illegal exploitation of timber and forest resources and poaching of endangered species of wildlife as well as violation of urban plan regulation on location of petrol filling station and GSM mast among others. 
- Weak institutional capacity - the enforcement institutions lack the necessary measurements of environmental performance due to low levels of technology and weak capacity to enforce environmental regulations.

- Poor governance - lack of political will. The government has not demonstrated the seriousness required to effectively enforced environmental regulations.

- Vested interest mostly by people in position of authority and as such, they will rather prefer to look the other way round because enforcing the regulations will jeopardize their interest.

- Absence of rule of law - the dominance of informal institutions in the country often makes formal law to be disregarded, or at most considered less important. This high degree of informality contributes to the high levels of corruption and informal patronage in structuring political power. Also, policies and institutions on the environment, where they exist, treat environmental challenges with daunting levity.

- Under staffing - most enforcing institutions are grossly under staffed, making it difficult for them to effectively enforce environmental regulations.

- Arbitrary arrests by the Police.

- Multiplicity of legislation from the Federal, State and Local Government level with no clear-cut regulatory framework has made enforcement of environmental laws and regulation difficult. There are many agencies and departments charged with responsibility of protecting the environment that has overlapping functions which made enforcement difficult.

- Corruption - this has become endemic in the country. Most often, violators of environmental laws and regulations left unpunished with little gratification to enforcement officers. This leads to continuous reduction and degradation in environmental quality in the country.

- Inadequate funding of the enforcement institutions - budgetary allocation to environmental sector is oftentimes small, yet, this small amount is hardly released in full to the sector. The gross inadequacy of funding greatly constrained the enforcement of environmental laws and regulations.

- Ignorance - there is high level of ignorance about environmental laws and regulations among both the literate and non-literate segments of the Nigeria population. This constitute serious challenges to compliance to environmental laws and regulations in the country [13].

\section{Recommendations}

Based on the findings of the study, the following recommendations were suggested;

- Review of some of the outdated environmental laws and regulations in line with global best practices to reflect current reality.

- Strengthening of institutional capacity through the provision of required technological equipment support and training.

- Employment of more staff to meet the required manpower need of the enforcement agencies.

- Increase funding of the environmental sector through increase budgetary allocation and mobilization of fund for environmental protection activities

\section{Conclusion}

This study has examined the role of enforcement in environmental protection in Nigeria. The study adopted secondary desk review of relevant materials. The findings of the study reveals that despite the numerous environmental laws and regulations enacted by the government, compliance has been greatly constrained by lack of or poor enforcement. The some of the major challenges to the poor enforcement are lack of political will on the part of Government, vested interest, ineptitude, poor funding, inadequate staff, poor logistics and ignorance. Thus, effective enforcement of environmental legislation in Nigeria will require strong commitment on the part of the government. 


\section{Compliance with ethical standards}

\section{Acknowledgments}

The authors express their appreciation to all those involved in enforcement of environmental regulations and protection of the Nigerian environment. The authors also acknowledge with gratitude all the authors whose materials was used in this work especially Christian Ichite and Professor Muhammed Tawfiq Ladan (PhD).

\section{Disclosure of conflict of interest}

The authors wish to state that there is no any conflict of interest in this publication.

\section{References}

[1] Ichite C. (2017). An Appraisal of Frameworks on Environmental Security in Nigeria. Lap Lambert Academic Publishing Co.

[2] United Nations Environment Programme (UNEP). (2014). Enforcement of Environmental Law: Good Practices from Africa, Central Asia, ASEAN Countries and China. UNEP Document Repository.

[3] IMPEL. (1992). 'Principles of Environmental Enforcement'.

[4] Institute of Environmental Management and Assessment. (IEMA). (2005). Managing compliance with environmental law: a good practice guide. Best Practice Series, 6.

[5] Wasserman CE. (1992). Principles of Environmental Enforcement. Washington, D.C.: U.S. Environmental Protection Agency.

[6] International Network for Environmental Compliance and Enforcement. (INECE). (2009). Principles of Environmental Compliance and Enforcement Handbook. Washington.

[7] Spulber DF. (1989). Regulation and Markets. Boston: MIT Press.

[8] Stavropoulos S, Wall R and Xu Y. (2018). Environmental regulations and industrial competitiveness: evidence from China, Applied Economics, 50(12), 1378-1394.

[9] Ijaiya H and Joseph OT. (2014). Rethinking Environmental Law Enforcement in Nigeria. Beijing Law Review, 5, 306-321.

[10] Dasgupta Partha and Maler Karl-Goran. (1995). Poverty, institutions, and the environmental - resource base. World Bank environment paper, 9.

[11] World development report. (2002). Building Institutions for Markets. World development report. Washington, D.C: World Bank Group.

[12] Ladan S. (2007). The Environment and Environmental Law in Nigeria. Environmental Watch Journal, 1(1), 232 242.

[13] Ladan MT. (2009). Law, Cases and Policies on Energy Mineral Resources, Climate Change, Environment, Water, Maritime and Human Rights in Nigeria. Ahmadu Bello University Press, Zaria, Nigeria, at, 97-98.

\section{How to cite this article}

Oruonye ED and Ahmed YM. (2020). The role of enforcement in environmental protection in Nigeria. World Journal of Advanced Research and Reviews, 7(1), 48-56. 